\title{
Pierre Robin sendromlu olguda anestezi sırasında görülen ani kardiak arrest
}

\section{Sudden cardiac arrest occurred during anesthesia of a patient with Pierre Robin syndrome}

\author{
Cevdet Düger*, Ahmet Cemil İsbir, Kenan Kaygusuz, İclal Özdemir Kol, Sinan \\ Gürsoy, Caner Mimaroğlu
}

Anesteziyoloji ve Reanimasyon Anabilim Dalı (Yrd. Doç. Dr. C. Düger, Yrd. Doç. Dr. A. C. İsbir, Doç. Dr. K. Kaygusuz, Doç. Dr. İ. Özdemir Kol, Prof. Dr. S. Gürsoy, Prof. Dr. C. Mimaroğlu), Cumhuriyet Üniversitesi Tıp Fakültesi, TR-58140 Sivas

Geliş tarihi/Received: 04 Ağustos 2011; Kabul tarihi/Accepted: 04 Nisan 2012

\author{
*İletişim adresi: \\ Dr. Cevdet Düger, Anesteziyoloji ve Reanimasyon Anabilim Dalı, Cumhuriyet Üniversitesi Tip \\ Fakültesi, TR-58140 Sivas. E-posta: cevdetduger@ gmail.com
}

\section{Sayın Editör}

Pierre Robin Sendromu mikrognati ve relatif makroglossi ile yarık damak bileşenlerini içermektedir [1]. Bunun yanında ilerleyen yıllarda mental retardasyon, fasial dismorfizm, kardiyak defektler, ve kas iskelet anomalileri görülebilir [1]. Pierre Robin sendromlu hastalar havayolu obstrüksiyonu için yüksek risk altındadır ve hipoksemi, kor pulmonale, kuvvet kaybı ve serebral anoksi gelişme ihtimali yüksektir. Obstrüktif uyku apnesi ve horlama özellikle ileri yaş hastalarda sıktır. Pierre Robin sendromunda en sık ölüm nedeni aspirasyondur [2]. Biz burada Pierre Robin sendromu tanısı almış bir hastada operasyon esnasında görülen kardiyak arrest durumunu sunmaktayız.

Altmış sekiz günlük, 2060 gr ağırlığında, prematüre doğum öyküsü olan, erkek hastanın dil asma operasyonu nedeniyle anestezi alması planlandı. Hasta anestezi öncesi muayene esnasında entübe halde mekanik ventilatör desteğinde, bilinci açık halde iken pediatri yoğun bakımında takipte idi. Hastada mikrognati, yarık damak mevcuttu. Aspirasyon şüphesi ile 1 hafta kadar önce aspirasyon pnömonisi tedavisi alan hastanın muayene esnasındaki $\mathrm{SPO}_{2}$ : 100, kan basınc1 86/50 mmHg, nabız 130 atım/dakika idi. Kardiyak muayenesi normal olarak değerlendirildi. Antibiyotik tedavisinin tamamlanmasının ardından tekrar görülmesi sonrasında operasyona engel görülmeyen ve vital bulguları stabil olan hastanın operasyondan yarım saat önce self ekstübasyona uğradığı ve yeniden entübe edilememesi üzerine operasyon odasına spontan solur vaziyette hızla indirildiği ve bu şekilde takip edildiği pediatri kliniğince belirtildi. Operasyon odasına $\mathrm{SPO}_{2} \% 70$ ve nabız 75 atım/dk olarak gelen hasta acilen entübe edildi ve sevofluran \%2-3 ve $\% 100 \mathrm{O}_{2}$ ile anestezi idamesi sağlandı. Hastanın $5 \mathrm{dk}$ sonra $\mathrm{SPO}_{2} \% 100$ ve nabız 120 atım/dk değerlerine çıktığı görüldü. Yeterli anestezi derinliği sağlandıktan sonra hasta cerrahi ekibe teslim edildi. Cerrahi ekip hastanın hazırlığını asepsi ve antisepsi kurallarına uygun tamamladıktan sonra entübasyondan yaklaşık 15 dakika sonrasında, dil kökü sütürü geçilmesi esnasında hastada ani bradikardi ve kardiyak arrest gözlendi. Hasta 45 dakika süreyle yapılan kardiyopulmoner resüsitasyona cevap vermedi ve eksitus olarak kabul edildi.

Pierre Robin Sendromlu hastaların anestezisi havayolu obstrüksiyonları ve zor havayolu nedeniyle sikıntılıdır [1]. Hayatın ilk aylarında spontan solunuma olanak vermeyecek derecede havayolu obstrüksiyonu görülen hastaların havayolu mutlaka kontrol altına 
alınmalıdır. Buradaki hasta dil kökünün havayolunu tıkaması nedeniyle entübe edilerek havayolu kontrol altına alınmış ve mekanik ventilatöre bağlanmıştır. Hastanın operasyonu elektif şartlarda planlanmış ve hazırlıkları tamamlanmasının ardından operasyona girmeden kısa bir süre önce hastanın havayolu kontrolü ortadan kalkmış entübasyon güçlüğü nedeniyle entübe edilemeyen ve spontan soluyan hasta düşük bir $\mathrm{SPO}_{2}$ ile operasyon odasına alınarak havayolu kontrolü sağlanmış ve vital bulgularının stabil görülmesi üzerine genel anestezi işlemi uygulanmıştır. Anestezi esnasında ölümlerin \%30 unun entübasyon esnasında görüldügüü bildirilmiştir [3]. Bu olguda anestezi esnasında havalanma ile ilgili herhangi bir problem yaşanmamıştır. Pierre Robin sendromlu hastalarda ventriküler septal defekt, atriyal septal defekt, patent duktus arteriyozus ve aort koarktasyonu gibi konjenital kalp anomalilerinin de görülebileceği çeşitli yayınlarda bildirilmiştir [1,4]. Her ne kadar bu olguda yapılan kardiak sistem muayenesi normal gözlense de operasyon öncesi ekstübasyon nedeniyle hastanın maruz kaldığı hipoksi ve muayene ile tespit edilemeyen muhtemel bir konjenital kardiyak anomalinin ani gelişen böylesi bir kardiyak arreste neden olabileceği kanaatindeyiz.

Sonuç olarak; Pierre Robin sendromlu pediatrik hastalarda havayolu kontrolünün zor olması sebebiyle havayolu kontrolünün dikkatle yapılması ve özellikle bu yaş grubu hastalarda self ekstübasyon riskinin ve tespit edilmesi zor muhtemel kardiyak anomali nedeniyle gelişebilecek ani kardiyak arrest varlığının akılda tutulması gerektiğini düşünüyoruz.

\section{Kaynaklar}

1. Rasch DK, Browder F, Barr M, Greer D. Anaesthesia for treacher collins and Pierre Robin syndromes: a report of three cases. Can Anaesth Soc J 1986; 33: 364-70.

2. Atalay C, Aykan Ş, Alıcı HA, Erdem AF, Can A. İleri yaş Pierre Robin sendromunda uyanık fiberoptik entübasyon: Bir olgu. Yeni Tıp Dergisi 2008; 25: $107-9$.

3. Kaya K, Gökağaçlı R, Öztürk E. Entübasyonda güçlük ve laringoskop gerektirmeyen teknikler. Anestezi Dergisi 1996; 4: 57-68.

4. Gollin RJ. Syndromes of the Head and Neck. 2nd ed. New York: McGraw-Hill, 1976. 